\title{
DEVELOPMENT OF A COMPUTER PROGRAM USING VISUAL BASIC FOR PREDICTING PERFORMANCE PARAMETERS OF TILLAGE IMPLEMENTS
}

\author{
Saad Al-Hamed ${ }^{1}$, Mohammed Wahby ${ }^{1}$, Abdulwahed Aboukarima ${ }^{2}$ \\ and Khaled Ahmed ${ }^{3}$
}

\begin{abstract}
This research effort is looking at alternatives to equation-based modeling; the ability to make predictions without creating equations to describe variable relations satisfies the research goals. A program for predicting performance of tillage implements in visual basic based on trained artificial neural network was developed. The program was designed to predict the required draft and energy of chisel, moldboard and disk plows. Field efficiency for each plow was assumed. The results of the program application are found almost identical with actual performance data of the selected plows. The fuel consumption could be determined through rated PTO power of a tractor. Hence, the developed program can be used to aid decision - makers in selecting the optimum tractor-machine complement size during operation under specific conditions of the soil and both plowing speed and depth. The specifications of each plow were considered as inputs in the program. The benefit of the program is to assist graduate and undergraduate students in agricultural engineering field to estimate data performance of tillage implements.
\end{abstract}

1Professor, Dept. of Agric. Eng., Coll.of Food and Agric. Sci., King Saud University, Saudi Arabia.

${ }^{2}$ Senior Res., Agric. Eng. Res. Inst., Agric. Res. Centre, Egypt and currently he is working as Assistant Professor at Shaqra University, Saudi Arabia.

${ }^{3}$ Researcher, Agric. Eng. Res. Inst., Agric. Res. Centre, and currently he is working as Assi. Prof. at Dept. of Agric. Engi., College of Food and Agric. Sci., King Saud Univ., Saudi Arabia. 


\section{INTRODUCTION}

Tn agriculture crop production system, tillage is considered an essential process. However, the required energy for it represents a significant share of the energy needed in the crop production (Askari and Khalifahamzehghasem, 2013). Usually the required draft of a specific tillage implement working under different field and operation settings has measured using particular instrumentation systems (Elashry et al., 1994; Al-Janobi, 2000; Al-Jalil et al., 2001; Adamchuk et al., 2003; Bentaher et al., 2008; Al-Suhaibani et al., 2010; Younis et al., 2010). Such instrumentation systems are considered completely for an exacting tractor and not simply adjustable to other tractors (Al-Suhaibani et al., 2010). On the other hand, the required draft of a specific tillage implement can be measured directly by using strain gage load cells, hydraulic dynamometer or spring dynamometer. Wide reviews on various instrumentation systems used in measuring the required draft of tillage implements and other performance parameters for such implements are obtainable from literature (Al-Janobi and Al-Suhaibani, 1995 and 1996; Al-Janobi et al., 1997 and 1998; Al-Suhaibani et al., 1994; Al-Suhaibani and Al-Janobi, 1996).

Different draft empirical models developed by statistical analysis to predict the required draft of tillage implements are available in literature (Gee-Clough et al., 1978; Oskoui and Witney, 1982; Oskoui et al., 1982; Elbanna, 1989; El Khadrawy, 1990; Elbanna, 1992; Kheiralla et al. 2004; Sahu and Raheman, 2006; Rashidi et al., 2013.). Draft models could be also developed by dimensional analysis (Olatunji and Davies, 2009; Nkakini and Douglas, 2012; Moeenifar et al., 2013a, 2013b) or by fuzzy table look-up scheme (Mohammadi et al., 2012). Moreover, predicting tractor power requirements could be available using decision support system (Vishal et al., 2013).

The models which are used to predict draft, pull and energy requirements of tillage implements could be built by the help of artificial neural networks (Hassan and Tohmaz, 1995; Tohmaz and Hassan,1995; Kushwaha and Zhang, 1997; Zhang and Kushawaha,1999; Choi et al.,2000; Al-Janobi et al.,2001; Aboukarima et al. 2003; El Awady et 
al.,2003; El Awady et al., 2004; Aboukarima, 2004; Aboukarima and Saad, 2006; Aboukarima, 2007; Roul et al., 2009; Al-Janobi et al., 2010; Lai et al., 2010; Altinisik et al., 2012; Carman and Taner, 2012; Aboukarima, 2013; Saleh and Aly, 2013; Taghavifar and Mardani, 2013a and 2013b; Taghavifar et al., 2013a and 2013b). One of the reasons in which leads researchers to use artificial neural networks in building models is its powerful estimation and there is no specific material relation between the dependent and independent variables (Alimardani et al., 2009).

In scientific investigations, models could be a good tool to participate in resource management (Graves et al., 2002). In addition, a model enables researchers to manage their theoretical ideas and experimental explanations and to assume the reasonable implications of their investigations (Fishman, 1973). It can also be used in predicting or as forecasting tools (Muthuri, 2004) that help users make sensible educated guesses about future behaviour. As example, in farm machinery field, Sogaard et al. (1996) built a model for optimal selection of farm implements sizes within specific boundary conditions. In addition, other model designed by spreadsheet was developed by Al-Hamed et al. (1994) to estimate tractor performance. Moreover, a program for predicting tractor performance in Visual C++ was also built by Al-Hamed and AlJanobi (2001). Generally, tractor simulation and prediction models programmed by computer languages could be a successful tool to save time and field experiments (Catalan et al., 2008) and represent a necessarily cost-free tool to the determination of the relative importance of a number of variables affecting actual tractor operation. On the other hand, there are four criteria that can be used to select the preferable model. These are: prediction precision, model simplicity, evenness of parameter estimates and sensitivity of results to change in parameter (Hesse and Keuper, 2001). In spite of these criteria are granted the suitable selection of a model for specific case, a model to evaluate the draft force of farm implements with good accuracy is often complicated (Amara et al., 2013). 
Al-Janobi et al. (2010) developed an educational program to assist graduate and undergraduate students to estimate fuel consumption for tillage equipment. It supports to select the appropriate power of an agricultural tractor to operate with a particular tillage implement in specific operation and soil conditions to minimize fuel consumption. The program was written in visual $\mathrm{C}++$ programming language. The program was based on training library of an artificial neural network. The program offers an educational help and clarification to most of the affecting parameters on fuel consumption. The program was validated by comparing predicted fuel consumption with the results obtained during field experiments. The program has proven to be very user-friendly and efficient to meet the requirement.

Hassan et al. (2011) developed a program for predicting performance of agricultural machinery in visual basic. The program predicts field efficiency, field capacity, draft power required to operate machines and PTO power. This program helps machinery management and could be used as educational and research tool. The formulas used in building the program are gathered from literature and the program was written in Visual Basic programming language as user-friendly interactive program. The program provides an intuitive user interface by linking to built-in databases were made available for the standard values of machinery specifications parameters to predict the performance of a selected agricultural machine otherwise, the user is prompt to enter his relevant input data for the model. The program has been statistically validated and proven to be user friendly and efficient.

Pranav et al. (2012) developed user friendly software for predicting the performance of power tiller to meet requirements in educational and research organizations by using visual basic. The software was based on Brixius equations rolling radius, gross traction ratio) and motion resistance ratio and slip was calculated by iteration. The developed software was validated by conducting experiments with a $6.7 \mathrm{~kW}$ power tiller. The results simulated by software indicate lower draft and slip in the range of 1-23 and 2-9\% with respect to the experimental data. 
Although instrumentation systems could be designed for draft measurements to be relatively inexpensive, portable, low maintenance, and easily adaptable to the tractors available at each site (Graham et al., 1990) and availability of different types of dynamometers for measuring such draft of a tillage implement, but the field work is hard and expensive to make a complete field performance data. Besides, draft force varies greatly due to numerous factors including soil condition like moisture content, texture and bulk density, forward speed, depth and tool geometry (Mouazen and Ramon, 2002; Godwin et al., 2007; Rashidi et al., 2013; Mahfoud and Ilham, 2013). Currently visual basic and visual $\mathrm{C}++$ are widely used to develop a computerized tractor simulation and prediction model based that calculates drawbar (Catalan et al., 2008). On the other hand, the visual basic environment facilitates could be used with artificial neural network to implement computerized prediction model for draft requirements. So, it is necessary to have a simple, accuracy and friendly interactive computer program to predict and estimate the required performance data of tillage implements. Thus, this research work was undertaken to develop a program for predicting performance of tillage implements in visual basic based on trained artificial neural network. This program is useful for research and educational purposes as it depends on working and field conditions in wide ranges.

\section{MATERIALS AND METHODS}

\section{Draft data collection and calculations}

Available draft data of chisel, moldboard and disk plows in literatures, which directly related to the subject, were collected from different literature and field experiments (Project No. 09-SPA876-02, National Plan for Science and Technology King Saud University, Saudi Arabia). The studies in literature executed field or laboratory experiments using the plows in soils having different moistures, bulk densities and textures with different changeable working conditions and plows geometries. Collected data set was consisted of 130 data points for disk plow. However, Godwin and O'Dogherty (2007) made Microsoft Excel spreadsheet that incorporated moldboard plow draft prediction. This spreadsheet is straightforward to use. In the project, this spreadsheet was 
used to predict draft requirements of different moldboard plows available in Saudi farms (Table 1) by the help of soil mechanical properties (cohesion, soil internal friction angle, soil metal friction angle and soil adhesion) for different studied regions. After suggesting plowing speed and depth, several draft data were available considering plow specifications (share approach angle, moldboard angle and rake angle). The created moldboard draft data were 3720 rows.

In the project, soil texture index (STI, dimensionless) for moldboard and chisel plows ANN models will be formulated from sand, slit and clay as follows:

$$
S T I=\frac{\log \left(S a^{S i}+C C a\right)}{100}
$$

Where $\mathrm{Sa}, \mathrm{Si}$ and $\mathrm{CCa}$ are \% of sand, silt and clay fractions in the soil. However, Microsoft Excel spreadsheet to predict draft and vertical forces of single tool which presented by Godwin and O'Dogherty (2007) was used. It was able to calculate draft and vertical forces for user-desired soil properties and geometrical parameters. These calculations require soil bulk unit weight (specific weight, $\mathrm{kN} / \mathrm{m}^{3}$ ), (soil cohesion, $\mathrm{kN} / \mathrm{m}^{2}$ ), (angle of internal friction, degrees) and (angle of soil-metal friction, degrees). In addition to soil properties, this spreadsheet requires geometric and operating parameters of the tool, which are specific to the tool under consideration. For a single tine, relevant geometric parameters are tool width and rake angle. The operating parameters are the depth of operation and the forward speed. In the project, this spreadsheet was used to predict draft requirements of different chisel tools available in Saudi farms by the help of soil mechanical properties obtained in the project for different regions. After suggesting plowing speed and depth, several draft data were available considering plow specifications (tool width and rake angle). The final outcomes of these computations are the predicted values of draft and vertical forces values of 1342 data points. Table (2), Table (3) and Table (4) illustrate range of inputs for ANN modeling for disk, moldboard and chisel plows, respectively. 
Table (1). Specifications of moldboard plows available in some Saudi farms.

\begin{tabular}{|l|c|c|c|c|c|}
\hline \multirow{2}{*}{ Item } & \multicolumn{5}{|c|}{ Plow model } \\
\cline { 2 - 6 } & $\begin{array}{c}\text { ALPVEM } \\
\text { A-ARADO } \\
\text { IBS14- } \\
\text { 034E }\end{array}$ & $\begin{array}{c}\text { OVERU } \\
\text { M-S } \\
7073-31\end{array}$ & $\begin{array}{c}\text { Hb1-cd- } \\
81791\end{array}$ & $\begin{array}{c}\text { No model } \\
\text { available }\end{array}$ & $\begin{array}{c}\text { EBERHA } \\
\text { RDT }\end{array}$ \\
\hline Country & & Sweden & & & Germany \\
\hline $\begin{array}{l}\text { Share sweep } \\
\text { angle }\end{array}$ & 44 & 44 & 44 & 35 & 35 \\
\hline $\begin{array}{l}\text { Moldboard } \\
\text { angle }\left(^{\circ}\right)\end{array}$ & 38 & 39 & 39 & 35 & 35 \\
\hline $\begin{array}{l}\text { Point depth } \\
(\mathrm{cm})\end{array}$ & 6 & 6 & 5 & 6 & 7 \\
\hline $\begin{array}{l}\text { Point width } \\
(\mathrm{cm})\end{array}$ & 7 & 7 & 6 & 7 & 6 \\
\hline $\begin{array}{l}\text { Rake angle } \\
\left({ }^{\circ}\right)\end{array}$ & 20 & 23 & 21 & 22 & 20 \\
\hline $\begin{array}{l}\text { Share width } \\
(\mathrm{cm})\end{array}$ & 32 & 45 & 35 & 40 & 32 \\
\hline $\begin{array}{l}\text { Moldboard } \\
\text { length (cm) }\end{array}$ & 86 & 87 & 83 & 87 & 88 \\
\hline
\end{tabular}

Table (2). Range of inputs for disk plow.

\begin{tabular}{|l|c|c|c|}
\hline Parameters & Unit & Minimum & Maximum \\
\hline Disk angle & $\left({ }^{\circ}\right)$ & 40.00 & 55.00 \\
\hline Tilt angle & $\left({ }^{\circ}\right)$ & 15.00 & 25.00 \\
\hline Disk diameter & $(\mathrm{cm})$ & 53.00 & 66.00 \\
\hline Plowing speed & $(\mathrm{km} / \mathrm{h})$ & 1.20 & 10.00 \\
\hline Plowing depth & $(\mathrm{cm})$ & 6.70 & 23.40 \\
\hline Soil moisture content & $(\% \mathrm{db})$ & 4.90 & 28.00 \\
\hline Sand & $(\%)$ & 9.00 & 90.85 \\
\hline Silt & $(\%)$ & 4.00 & 48.00 \\
\hline Clay & $(\%)$ & 4.55 & 70.00 \\
\hline Soil density & $\left(\mathrm{g} / \mathrm{cm}^{3}\right)$ & 1.22 & 1.67 \\
\hline
\end{tabular}


Table (3). Range of inputs for moldboard plow.

\begin{tabular}{|l|c|c|c|}
\hline Parameters & Unit & Minimum & Maximum \\
\hline Moldboard angle & $\left({ }^{\circ}\right)$ & 35 & 39 \\
\hline Moldboard length & $(\mathrm{cm})$ & 83 & 88 \\
\hline Rake angle & $\left({ }^{\circ}\right)$ & 20 & 23 \\
\hline Share sweep angle & $\left({ }^{\circ}\right)$ & 35 & 44 \\
\hline Plowing speed & $(\mathrm{km} / \mathrm{h})$ & 2 & 8 \\
\hline Plowing depth & $(\mathrm{cm})$ & 12 & 25 \\
\hline Soil moisture content & $(\%)$ & 1.3 & 15.1 \\
\hline Soil bulk density & $\left(\mathrm{g} / \mathrm{cm}^{3}\right)$ & 1.4 & 1.98 \\
\hline Soil texture index & $(---)$ & 0.05779 & 0.3790 \\
\hline
\end{tabular}

Table (4). Range of inputs for chisel plow.

\begin{tabular}{|l|c|c|c|}
\hline Parameters & Unit & Minimum & Maximum \\
\hline Rake angle & $\left({ }^{\circ}\right)$ & 40 & 60 \\
\hline Tool width & $(\mathrm{cm})$ & 6 & 7 \\
\hline Plowing depth & $(\mathrm{cm})$ & 8 & 30 \\
\hline Plowing speed & $(\mathrm{km} / \mathrm{h})$ & 2 & 8 \\
\hline Soil moisture content & $(\%)$ & 2.75 & 10.65 \\
\hline Soil bulk density & $\left(\mathrm{g} / \mathrm{cm}^{3}\right)$ & 1.44 & 1.84 \\
\hline Soil texture index & $(---)$ & 0.05779 & 0.223456 \\
\hline
\end{tabular}

After collection of draft data of disk plow, required energy and unit draft were calculated. The width of cut (bd, $\mathrm{cm})$ may be adjusted on standard disk plows by changing the angle of the disks with respect to forward motion (Dumitru, 2009). In this study, actual width of cut (bd) of a disk can be expressed as (Alam, 1989):

$$
b d=\frac{2 \cos \beta}{\cos \alpha} \sqrt{d(D \cos \alpha-d)}
$$

Where $\beta$ is disk angle $\left(^{\circ}\right), \alpha$ is tilt angle $\left(^{\circ}\right), \mathrm{D}$ is disk diameter $(\mathrm{cm}), \mathrm{d}$ is plowing depth $(\mathrm{cm})$. The total plowing width $(\mathrm{Wd}, \mathrm{cm})$ is calculated as:

$W d=N \times b d$

Where $\mathrm{N}$ is the number of disks on the plow. The tillage energy was calculated according to Smith (1993) as follows: 


$$
\operatorname{Energy}(\mathrm{kW} . \mathrm{h} / \mathrm{ha} / \mathrm{disk})=\frac{(F d, \mathrm{kN} / \mathrm{disk}) \times(\mathrm{V}, \mathrm{km} / \mathrm{h}) \times(1000, \mathrm{~m} / \mathrm{km})}{(3600, \mathrm{sec} / \mathrm{h}) \times(E F C, h a / h)}
$$

Where $\mathrm{Fd}$ is draft force for disk plow and V is plowing speed. Field efficiency is the most frequently used factor in determining the effective field capacity (Lar et al., 2011). Thus, the effective field capacity (EFC) was calculated according to the following equation:

$$
E F C(h a / h)=T F C(h a / h) \times \eta
$$

where $\eta$ is the field efficiency and for tillage primary it was ranged from 70 to $85 \%$ (Powell, 2000). Field efficiency was assumed to be 0.8 . Further, TFC denotes theoretical field capacity and was calculated according to the following equation:

$$
\operatorname{TFC}(\mathrm{ha} / \mathrm{h})=\frac{(\mathrm{Wd}, \mathrm{m}) \times(\mathrm{V}, \mathrm{km} / \mathrm{h}) \times 1000}{\left(10000, \mathrm{~m}^{2} / \mathrm{ha}\right)}
$$

Unit draft (UD) is calculated according to the following equation:

$$
U D\left(N / \mathrm{cm}^{2} / \text { disk }\right)=\frac{F d, N / d i s k}{d, c m \times W d, c m}
$$

The developed neural network model for disk plow to predict draft, energy and unit draft was consisted of three layers, the input layer had 10 inputs, the hidden layer had 8 neurons and output layer had 3 parameters (draft, unit draft and energy requirement of disk plows). The inputs were plowing speed, sand content, silt content, clay content, soil moisture content, disk diameter, disk angle, tilt angle and soil density. Minimum and maximum output parameters were 920 and 8000 N/disk for draft, for unit drat, the minimum and maximum values were 0.46 and 3.04 $\mathrm{N} / \mathrm{disk} / \mathrm{cm}^{2}$, respectively and for energy requirements, the minimum and maximum values were 8.02 and $29.81 \mathrm{~kW} . \mathrm{h} / \mathrm{ha} / \mathrm{disk}$, respectively.

After collection of draft data of moldboard plow, the required energy and unit draft were calculated as follows:

$$
\text { Energy }(\mathrm{kW} . \mathrm{h} / \mathrm{ha})=\frac{(F m, k N) \times(V, \mathrm{~km} / \mathrm{h}) \times(1000, \mathrm{~m} / \mathrm{km})}{(3600, \mathrm{sec} / \mathrm{h}) \times(E F C, h a / h)}
$$


Where Fm is total draft for moldboard plow $(\mathrm{kN})$ and field efficiency is calculated according to Eq. (5) and TFC is calculated according to the following equation:

$T F C(h a / h)=\frac{(W b, m) \times(V, k m / h) \times 1000}{\left(10000, m^{2} / h a\right)}$

Where $\mathrm{Wb}$ is plowing width of moldboard plow and it was calculated as follows:

$W b(m)=b m \times N u$

Where bm is shear width of moldboard plow $(\mathrm{m})$ and $\mathrm{Nu}$ is the number of shares. Unit draft is calculated according to the following equation:

$$
U D\left(N / \mathrm{cm}^{2}\right)=\frac{F m, N}{d, c m \times W b, c m}
$$

The developed neural network model for moldboard plow to predict draft was consisted of three layers, the input layer had 9 inputs, the hidden layer had 12 neurons and output layer had 1 parameter (draft of moldboard plow).The inputs were plowing speed, plowing depth, rake angle, share sweep angle, soil moisture content, soil bulk density, soil texture index, moldboard angle and moldboard length. Minimum and maximum values for output parameter were 0.44 and $10.33 \mathrm{kN} /$ body, respectively.

After collection of draft data of chisel plow, the required energy and unit draft were calculated as follows:

The width of chisel plow $(\mathrm{W}, \mathrm{cm})$

$W=\frac{N c}{2} \times H$

Where $\mathrm{Nc}$ is number of tools, $\mathrm{H}$ is distance between two tools in the same raw $(\mathrm{cm})$.

Theoretical Field capacity (ha/h):

TFC $(\mathrm{ha} / \mathrm{h})=W(\mathrm{~cm}) \times$ Plowing speed $(\mathrm{km} / \mathrm{h}) / 1000$

Actual Field capacity (ha/hr):

$E F C(h a / h)=T F C(h a / h) \times \eta / 100$ 
Total draft $(\mathrm{kN})=\mathrm{Fc} * \mathrm{Nc} / 1000$

Where, Fc is draft for chisel tool (N/tool) and tillage energy (kW.hr/ha) can be obtained by:

$$
\text { Energy }(\mathrm{kW} . \mathrm{h} / \mathrm{ha})=\frac{(\text { Total draft }, \mathrm{kN}) \times(\mathrm{V}, \mathrm{km} / \mathrm{h}) \times(1000, \mathrm{~m} / \mathrm{km})}{(3600, \mathrm{sec} / \mathrm{h}) \times(E F C, h a / h)}
$$

$$
\text { Unit draft }\left(\mathrm{kN} / \mathrm{cm}^{2}\right)=\frac{(\text { Total draft }, \mathrm{kN})}{(W, \mathrm{~cm}) \times(d, \mathrm{~cm})}
$$

The developed neural network model for chisel plow to predict draft was consisted of three layers, the input layer had 7 inputs, the hidden layer had 10 neurons and output layer had 1 parameter (draft of chisel plow).The inputs were soil moisture content, soil bulk density, soil texture index, rake angle, plowing depth, plowing speed and tool width. Minimum and maximum values for output parameter were 137.4 and $6076.7 \mathrm{~N} /$ tool, respectively. The minimum and maximum value of field efficiency which feed to the software was 70 and $85 \%$, respectively.

\section{Considerations for computer program development}

There have been several research activities on ANNs over the years (Hwang, 2001; Medeiros and Pedreira, 2001; Zhang, 2001). ANNs have been successfully used for a variety of tasks in many fields of agriculture and become an acceptable tool for prediction. Furthermore, ANNs are used for quantitative modeling for researchers (Alhassan and Misra, 2011). The number of published papers related to ANN in agricultural field of scientific journals proves the importance and wide acceptability of it. One of the major characteristics of ANNs is that it serves as a promising alternative tool for forecasters. This is so, because its inherent nonlinear structure is particularly useful for capturing complex underlying relationships which can be found in many real world problems. In addition, ANNs are used today because apart from its versatility as tool for forecasting applications in nonlinear structured problems, they are good for modeling linear processes (Alhassan and Misra, 2011).

On the other hand, hybrid prediction techniques for farm management are the order of the day, which involve a combination of data driven models and knowledge driven models. So, in this research paper ANN prediction tool has been generated with visual basic GUI to predict the performance 
parameters of three common tillage implements for farm machinery management purposes within permissible tolerances. The prediction such parameters is done using multilayered feed forward network using standard back propagation method. Multilayered feed forward network is known as a supervised network because it requires a desired output in order to learn. The goal of this type of network is to create a model that correctly maps the input to the output using historical data so that the model can then be used to produce the output when the desired output is unknown. Besides, the back propagation algorithm is an iterative gradient algorithm designed to minimize the mean-squared error between the desired output and the actual output for a particular input to the network (Lendaris, 2004). Basically, back propagation learning consists of two passes through the different layers of the network: a forward pass and backward pass. During the forward pass the synaptic weights of the network are all fixed. During the backward pass, on the other hand, the synaptic weights are all adjusted in accordance with an error-correction rule (Lippmann, 1987). This algorithm may be found elsewhere (Lendaris, 2004). Back propagation is easy to implement, and has been shown to produce relatively good results in many applications. It is capable of approximating arbitrary non-linear mappings. The success of back propagation methods very much depends on problem specific parameter settings and on the topology of the network (Leonard, 1990).

In this research, training ANN models was accomplished using commercially available Qnet 2000 (Vesta Services, 2000). It is a software program for constructing, training and recalling predictions using neural networks. This package comes with a graphical user interface for constructing and training back-propagation neural networks. The software also comes with a Dynamic Link Library (DLL) file that provides software commands that can be used to send and receive data from the neural networks within the Visual Basic programming environment (Brown, 2005). However, execution of a trained network is just the process of feeding an array of inputs to the network and receiving back the appropriate array of outputs. This is handled by the Qnetsolv.dll that is part of Qnet2000. This integration can be performed by programmers who utilize programming languages that support standard Windows DLL access like Visual Basic programming environment. However, there is a dynamic program flow between the DLL file of the software shell and the 
definition file generated by the trained neural network. A front end Graphical User Interface (GUI), created in Visual Basic integrates the definition file through the relevant Dynamic Link Library and calls the trained neural network as and when necessary to give predictions once the inputs are entered in the Visual Basic form.

\section{Program development}

Microsoft Visual Basic was selected as the programming language for building the developed program for tillage performance parameters predictions. This selection because it can be compiled into an executable program for rapid execution, is compatible with integrating the ANN training data set and is the language most familiar to the developer. However, Visual programming provides a set of screens, object buttons, scroll bars, and menus. The objects can be positioned on a form, and their behaviours are described through the use of a scripting language associated with each one. The program is an interactive program where the user is prompt to enter the relevant input data for the model. Figures (1) through (7) show screenshots of the Graphical User Interface (GUI) for performance parameters of three tillage implements (chisel plow, disk plow and moldboard plow). These figures illustrate inputs and outputs GUI for the three implements.

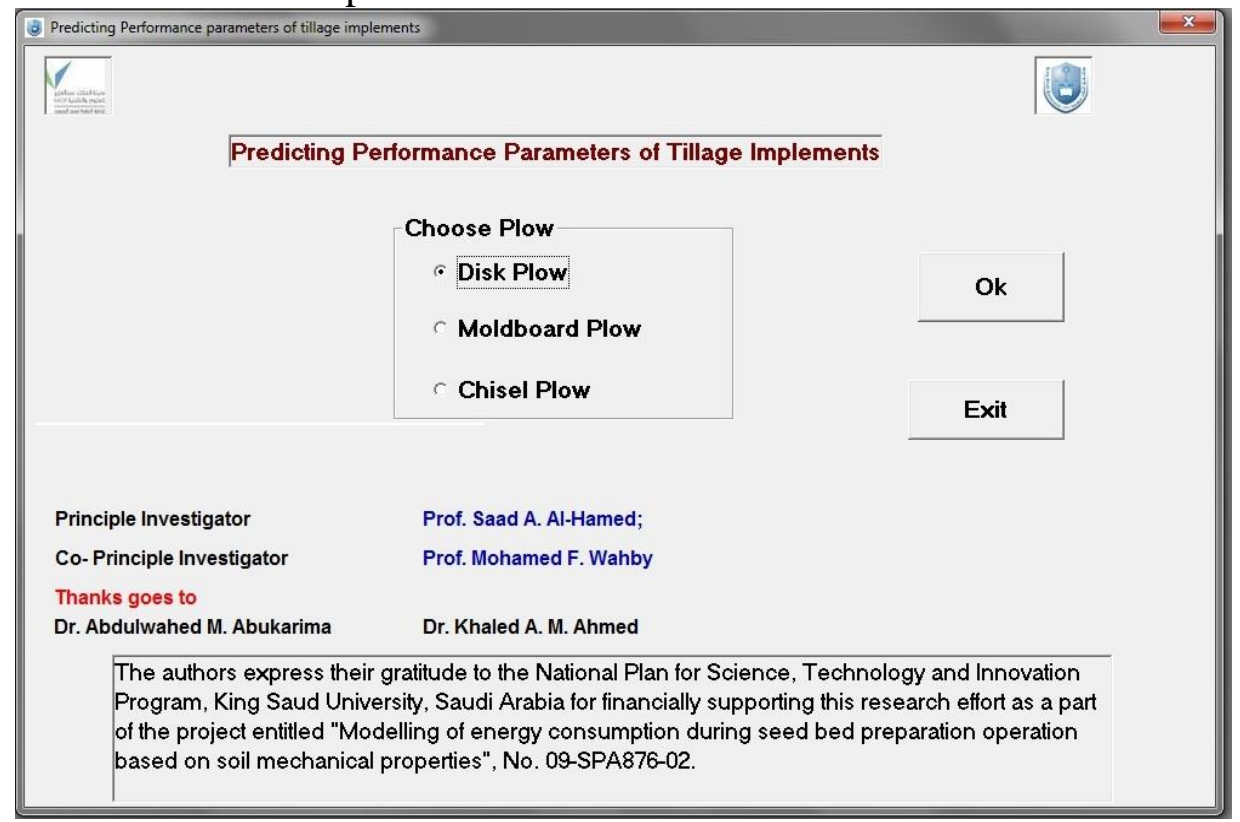

Figure (1). Screenshot of the first screen of the software for prediction of the performance parameters of tillage implements. 


\section{FARM MACHINERY AND POWER}

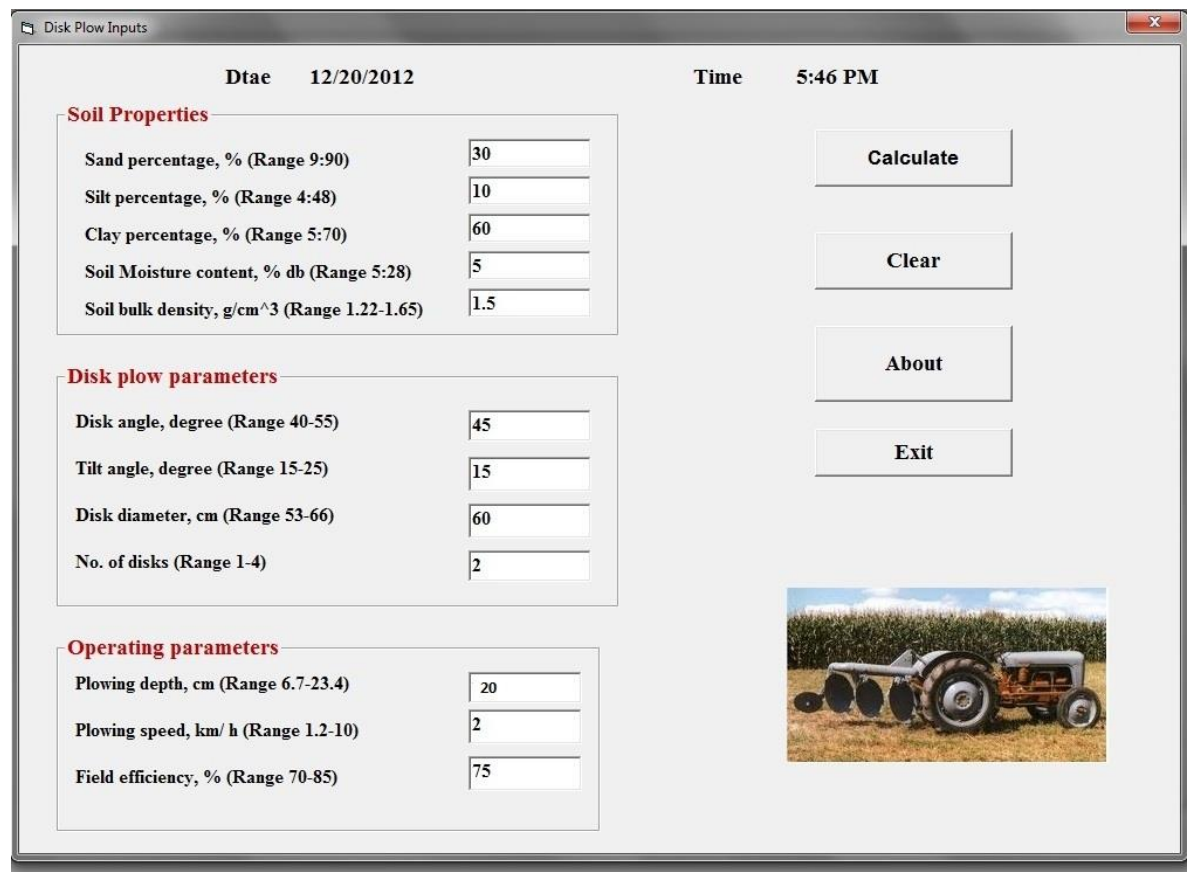

Figure (2). Screenshot of GUI inputs for disk plow.

\begin{tabular}{|l|l|}
\hline Disk Plow Output \\
\hline Disk Plow Outputs \\
\hline $12 / 20 / 2012$ \\
\hline Draft, N/disk
\end{tabular}

Figure (3). Screenshot of GUI of output parameters for disk plow. 


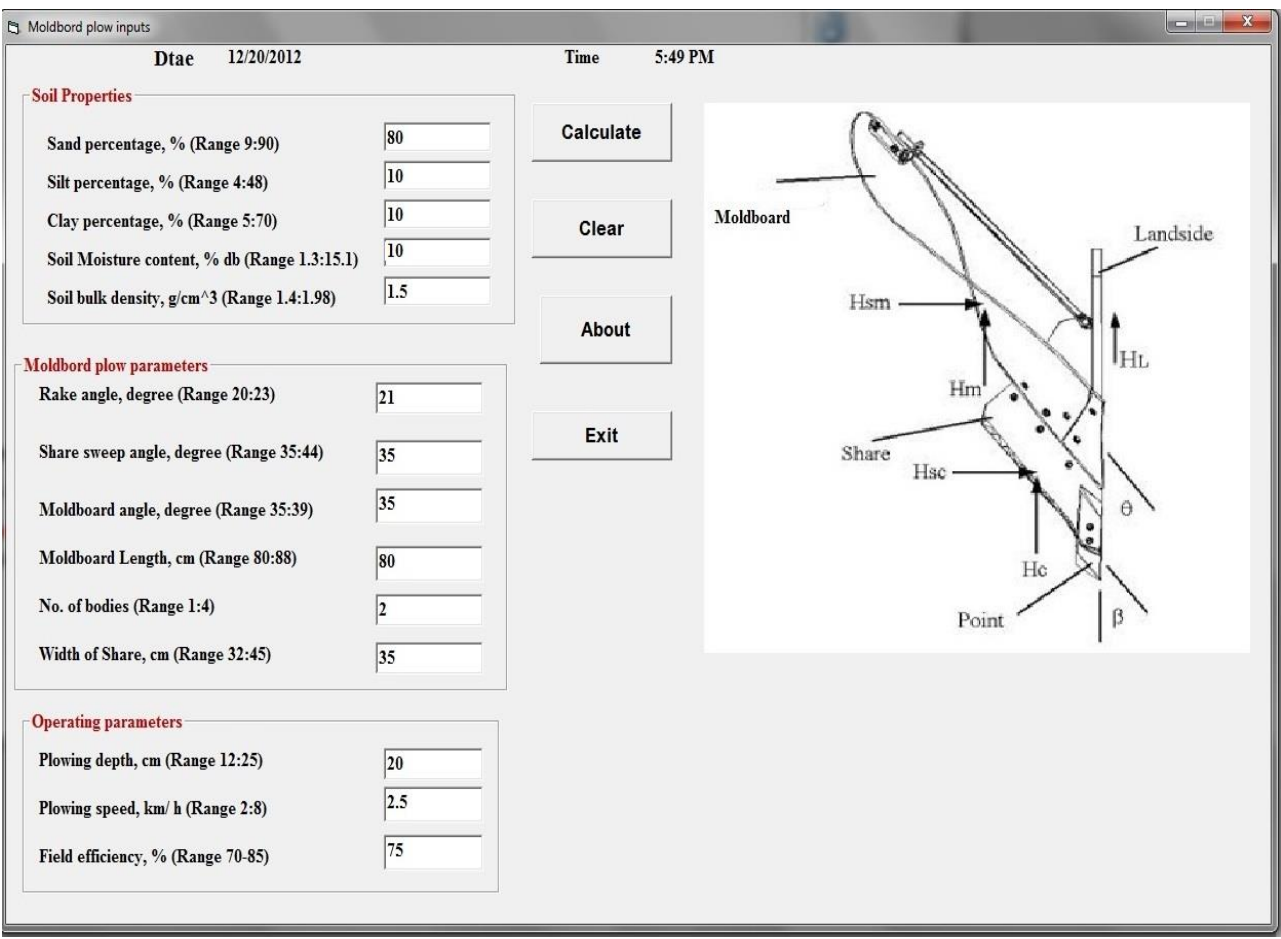

Figure (4). Screenshot of GUI of input parameters for moldboard plow.

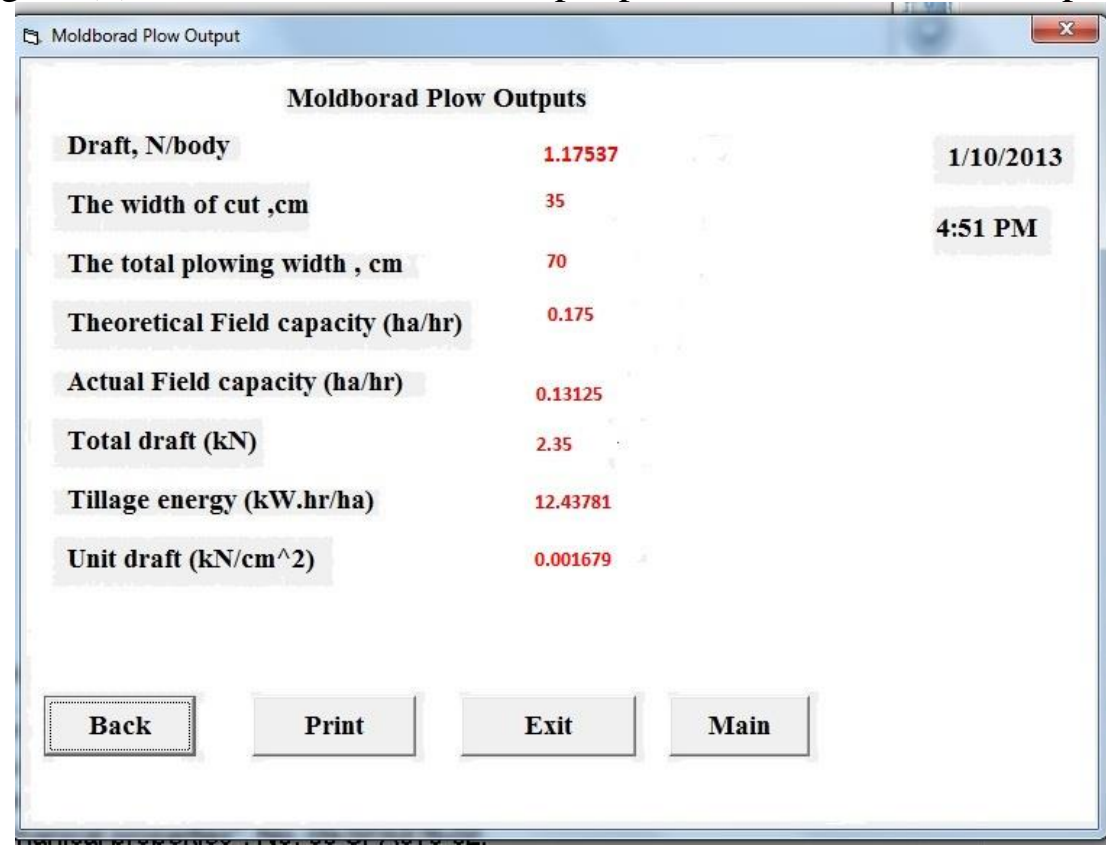

Figure (5). Screenshot of GUI of output parameters for moldboard plow. 


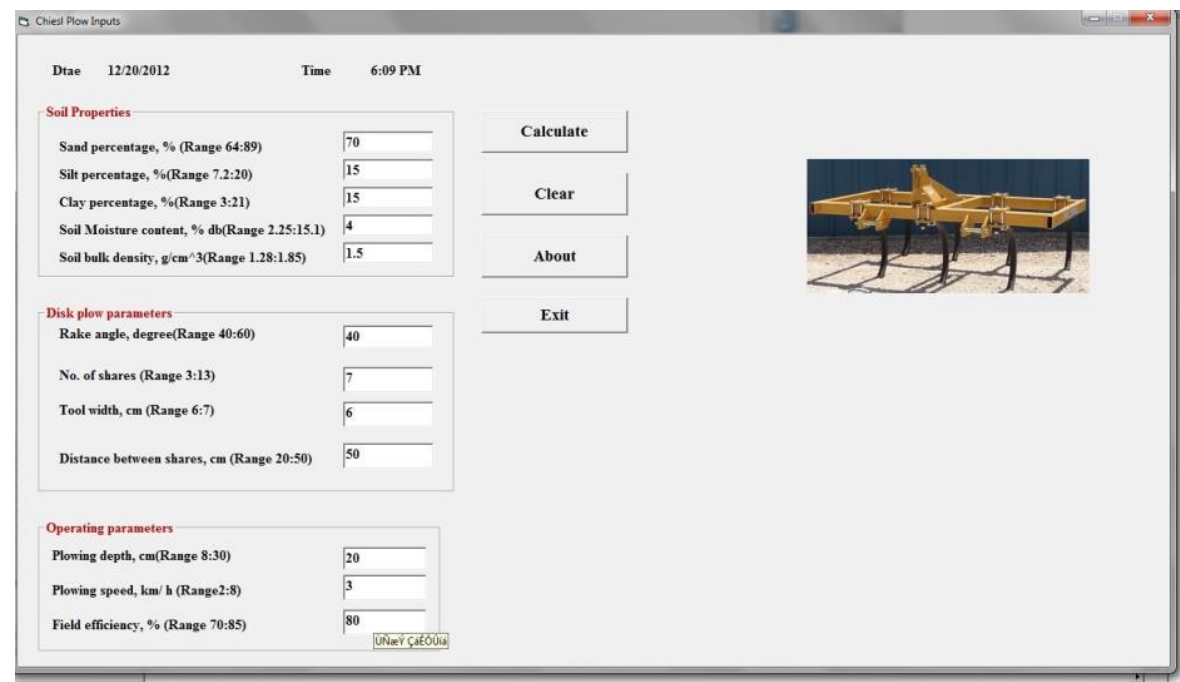

Figure (6). Screenshot of GUI of input parameters for chisel plow.

\begin{tabular}{|l|l|}
\hline Chiesl Plow Output & \\
\hline $1 / 10 / 2013$ & $4: 54$ PM \\
\hline Draft, N/tool & 485.921 \\
The total plowing width, cm & 175 \\
Theoretical Field capacity (ha/hr) & 0.525 \\
Actual Field capacity (ha/hr) & 0.42 \\
Total draft (kN) & 3.40 \\
Tillage energy (kW.hr/ha) & 6.74891 \\
\hline Unit draft (kN/cm^2) & 0.00648 \\
\hline Back Print & \\
\hline & Exit \\
\hline
\end{tabular}

Figure (7). Screenshot of GUI of output parameters for chisel plow.

\section{Program validation}

Once any model is built, it must be validated before use (Brown, 2005). A validation test means that the model accurately represents the real world system. To correctly validate a model, the actual system is tested over the range of values that the model will be used to predict. If acceptable agreement between the test data and the model is obtained that means, the 
model is validated. Field experiments were conducted using the three plows to get actual draft data at different texture, plowing speed, and depth, moisture content and bulk density for specific plow. Details of these experiments are offered in Al-Hamed and Wahby (2013).

For chisel plow, the field experiments were conducted using a chisel plow with 13 shanks. The characteristics of the soil for such experiments were depicted in Table (5) and the working conditions are illustrated in Table (6). The shank width was $7 \mathrm{~cm}$ and the rake angle was 55 degree.

Table (5). The characteristics of the soil for field experiments using a chisel plow with 13 shanks.

\begin{tabular}{|l|c|l|c|}
\hline Soil-metal friction angle & $21.66^{\circ}$ & Silt & $12.4 \%$ \\
\hline Soil internal friction angel & $36^{\circ}$ & Soil cohesion & $19.62 \mathrm{kPa}$ \\
\hline Clay & $3 \%$ & Sand & $84.6 \%$ \\
\hline Soil bulk density & $1.67 \mathrm{~g} / \mathrm{cm}^{3}$ & Soil adhesion & $10.72 \mathrm{kPa}$ \\
\hline Soil moisture content & $7.5 \% \mathrm{db}$ & & \\
\hline
\end{tabular}

Table (6). The raw data for field experiments using a chisel plow with 13 shanks.

\begin{tabular}{|c|c|c|}
\hline Plowing speed $(\mathrm{km} / \mathrm{h})$ & Plowing depth $(\mathrm{cm})$ & $\begin{array}{c}\text { Measured total draft } \\
(\mathrm{kN})\end{array}$ \\
\hline 2.50 & 15.1 & 4.11 \\
\hline 2.68 & 15.2 & 4.42 \\
\hline 3.38 & 15.2 & 5.31 \\
\hline
\end{tabular}

For moldboard plow, the field experiments were conducted using a moldboard plow had rake angle of 20 degree, share sweep angle of 44 degree, moldboard angle of 38 degree and moldboard length of $86 \mathrm{~cm}$. The characteristics of the soil for experiments using a moldboard plow with 2 bodies are illustrated in Table (5). The working conditions for moldboard plow are illustrated in Table (7).

For disk plow, the field experiments were conducted using Nardi, mounted category II, weight $362 \mathrm{~kg}$, Italy, model MF 38, serial No. TDPE48/D, with 3 disks with $36 \mathrm{~cm}$ disk diameter and distance between disks was $60 \mathrm{~cm}$, the disk angle and tilt angle were measured and they 
were $45^{\circ}$ and $16^{\circ}$, respectively. Characteristics of the soil in the experimental using disk plow are depicted in Table (8) and the working conditions are illustrated in Table (9).

Table (7). The raw data for field experiments using a moldboard plow with 2 bodies.

\begin{tabular}{|c|c|c|}
\hline Plowing speed $(\mathrm{km} / \mathrm{h})$ & Plowing depth $(\mathrm{cm})$ & $\begin{array}{c}\text { Measured draft } \\
(\mathrm{kN})\end{array}$ \\
\hline 2.69 & 21 & 3.81 \\
\hline 2.95 & 23 & 4.31 \\
\hline 3.08 & 18 & 3.33 \\
\hline 3.57 & 25 & 5.43 \\
\hline 3.87 & 18 & 3.68 \\
\hline 4.32 & 22 & 4.89 \\
\hline 4.56 & 16 & 2.85 \\
\hline 4.76 & 20 & 4.64 \\
\hline 5.83 & 22 & 5.85 \\
\hline 5.88 & 25 & 6.83 \\
\hline 6.28 & 18 & 3.57 \\
\hline 6.51 & 20 & 4.50 \\
\hline
\end{tabular}

Table (8). Characteristics of the soil in the experiments using disk plow.

\begin{tabular}{|l|c|c|}
\hline \multicolumn{1}{|c|}{ Items } & Unit & Value \\
\hline Sand & $(\%)$ & 83.2 \\
\hline Silt & $(\%)$ & 9.8 \\
\hline Clay & $(\%)$ & 7.0 \\
\hline Soil bulk density & $\left(\mathrm{g} / \mathrm{cm}^{3}\right)$ & 1.52 \\
\hline Soil moisture content & $(\% \mathrm{db})$ & 6.44 \\
\hline
\end{tabular}

Table (9). Raw data of the field tests during plowing with disk plow.

\begin{tabular}{|c|c|c|}
\hline Plowing speed $(\mathrm{km} / \mathrm{h})$ & Plowing depth $(\mathrm{cm})$ & Measured draft $(\mathrm{kN})$ \\
\hline 1.45 & 23 & 5.09 \\
\hline 2.27 & 23 & 5.43 \\
\hline 2.84 & 23 & 5.86 \\
\hline
\end{tabular}




\section{RESULTS AND DISCUSSION}

In the testing phase for chisel plow draft requirements ANN prediction model, standard deviation, bias, maximum error and correlation coefficient were $116.774 \mathrm{~N} /$ tool, $-14.042 \mathrm{~N} /$ tool, $773.347 \mathrm{~N} /$ tool and 0.992, respectively. Also, in the testing phase for disk plow draft, unit drat and energy requirements ANN prediction model, standard deviation, bias, maximum error and correlation coefficient were $794.465 \mathrm{~N} /$ disk, -0.997 N/disk, 2029.314 N/disk and 0.934, respectively for draft. For unit draft, standard deviation, bias, maximum error and correlation coefficient were $0.583 \mathrm{~N} / \mathrm{disk} / \mathrm{cm}^{2}, 0.016 \mathrm{~N} / \mathrm{disk} / \mathrm{cm}^{2}, 1.797 \mathrm{~N} / \mathrm{disk} / \mathrm{cm}^{2}$ and 0.993, respectively. For energy requirements, standard deviation, bias, maximum error and correlation coefficient were $2.793 \mathrm{~kW} . \mathrm{h} / \mathrm{ha} / \mathrm{disk},-0.175$ $\mathrm{kW} . \mathrm{h} / \mathrm{ha} /$ disk, $7.229 \mathrm{~kW} . \mathrm{h} / \mathrm{ha} /$ disk and 0.915, respectively. Meanwhile, in the testing phase for moldboard plow draft ANN prediction model, standard deviation, bias, maximum error and correlation coefficient were $0.25748 \mathrm{kN} /$ body, $0.00097 \mathrm{kN} /$ body, $1.31518 \mathrm{kN} /$ body and 0.988 , respectively. More details about training and testing such models are seen in Al-Hamed and Wahby (2013).

The developed software was used to predict the performance of plows at different operating conditions. It can predict additional values within the range of the training data set. After feeding the inputs to the software, the output parameter could be obtained and compared to measured data. For moldboard plow, the predicted draft from the developed program was compared to the results of field experiments where the effect of depth and speed on the horizontal (draft) forces of a general purpose moldboard plow were recorded in open field conditions. Figure (8) depicted the relationship between predicted drafts from the developed program and measured by field experiments for a moldboard plow. Meanwhile, Figure (9) depicted the relationship between predicted drafts from the developed program and measured by field experiments for a disk plow. Also, Figure (10) depicts the relationship between predicted drafts from the developed program and measured by field experiments for a chisel plow. 


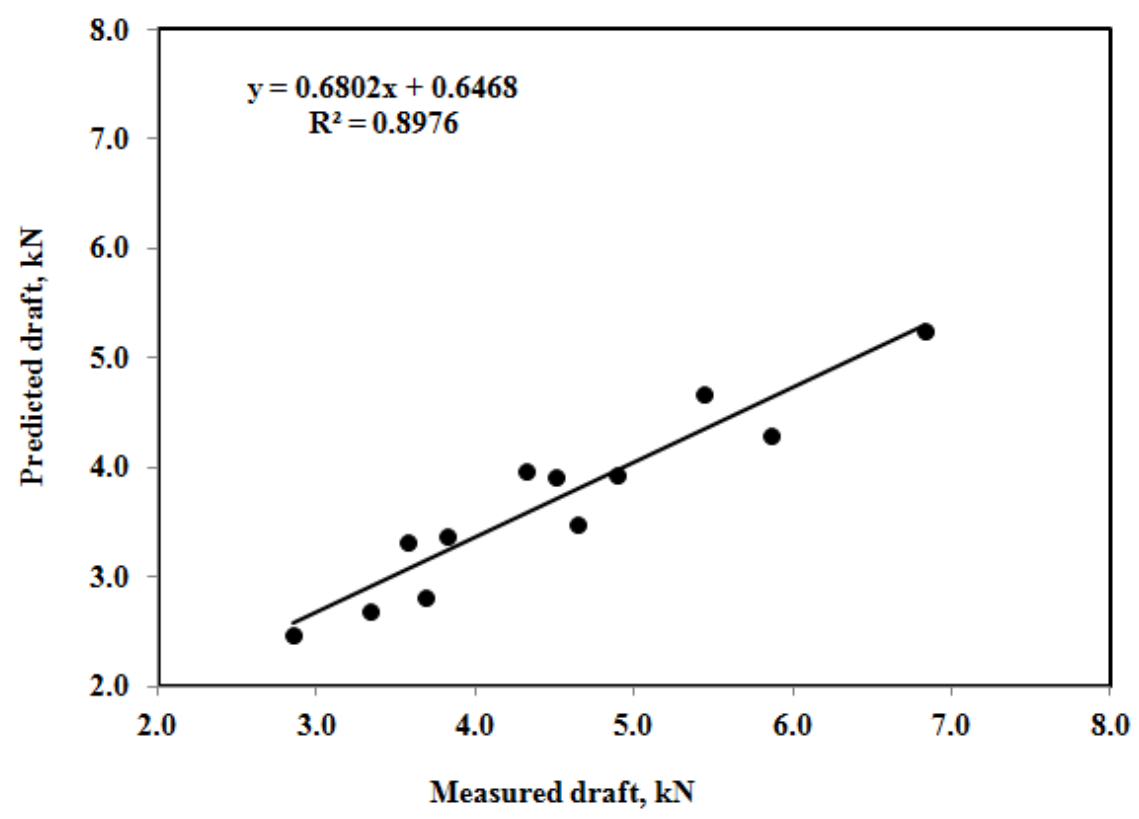

Figure (8). The relationship between predicted drafts from the developed program and measured by field experiments for a moldboard plow.

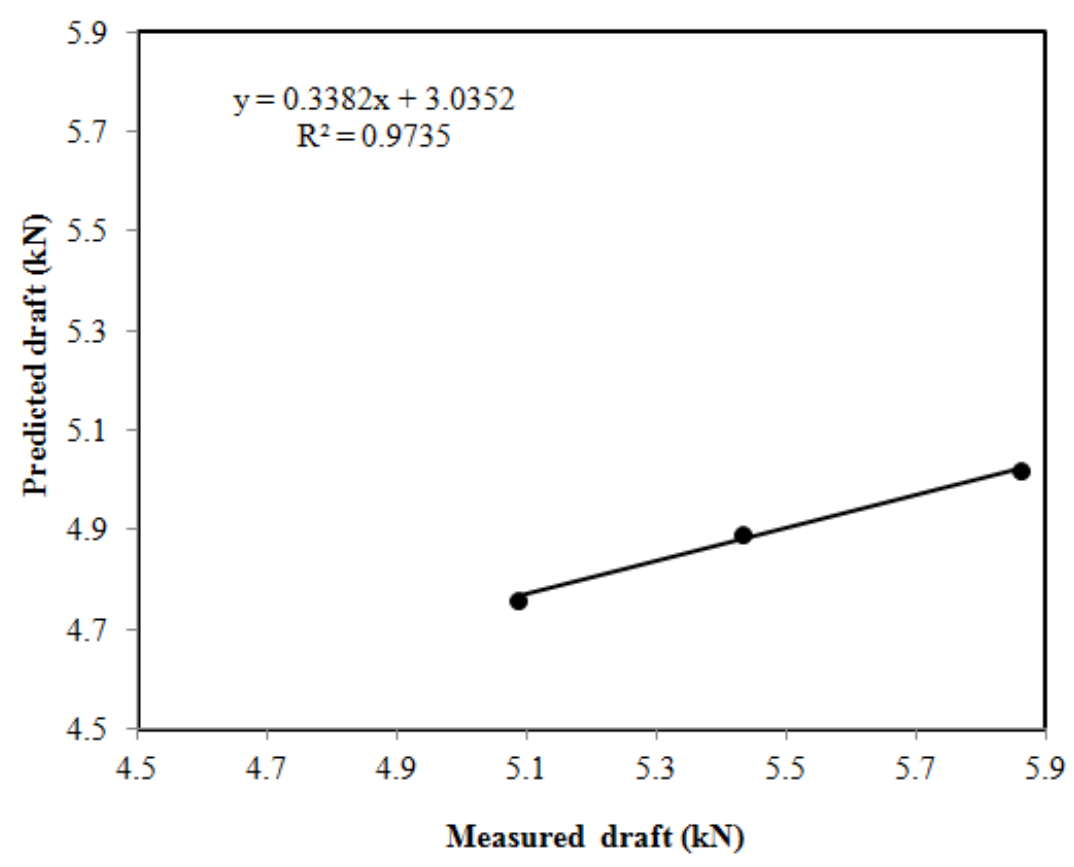

Figure (9). The relationship between the actual data of a disk plow from field experiments and the predicted values from the developed program. 


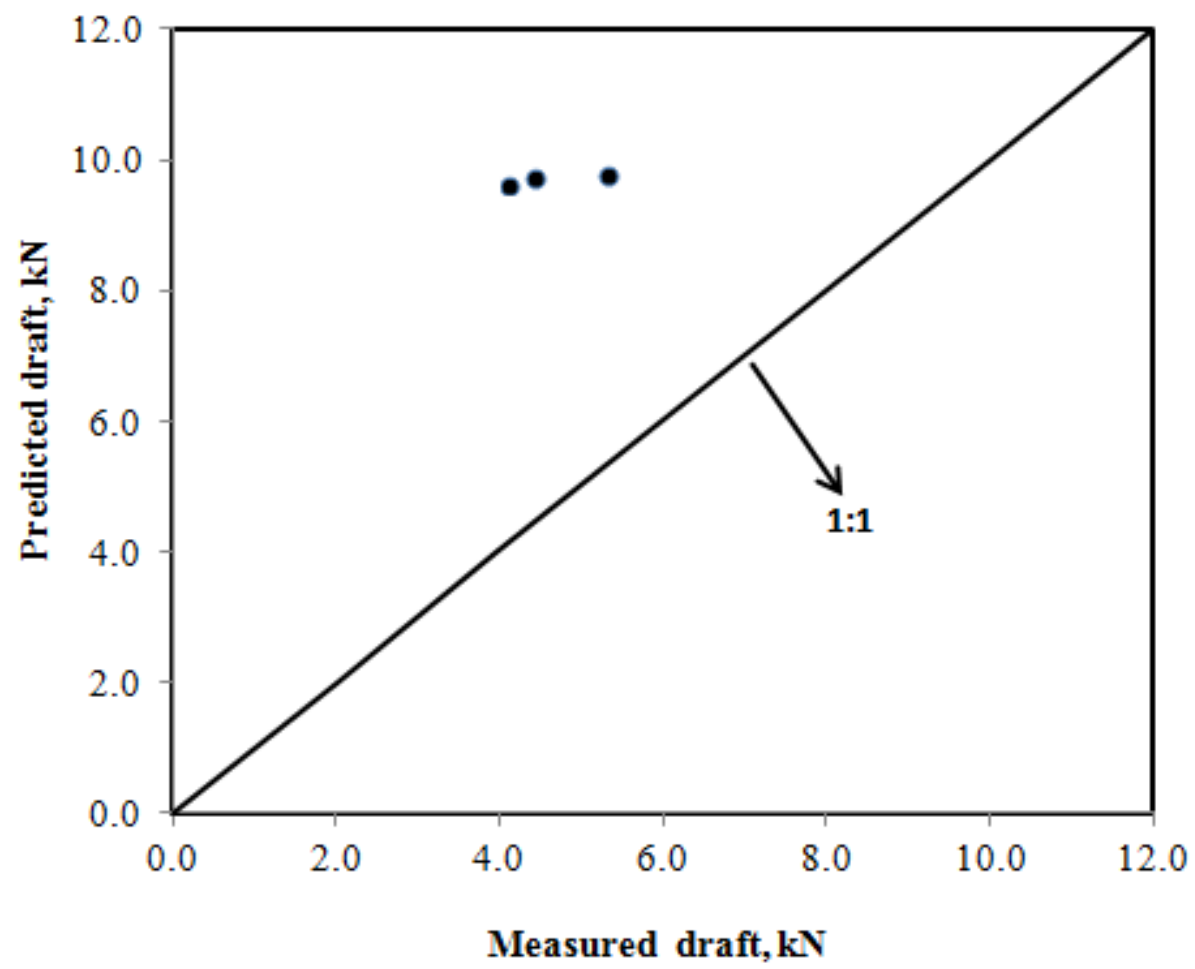

Figure (10). The relationship between predicted drafts from the developed program and measured by field experiments for a chisel plow.

By examining Figure (8) and Figure (9), it is obvious good agreements between measured and predicted draft from the developed program as confirmation from coefficients of determination $\left(\mathrm{R}^{2}\right)$ as shown in the figures which are around 0.9 .

\section{CONCLUSION}

A program in visual basic was written based on trained ANN models to predict drat data of three tillage implements namely chisel, disk and moldboard plows. This predication could be done at varying operating and soil conditions. The program mainly predict the draft, unit drat and energy. The program was validated for its operational behavior using real experimental data. The results found to be satisfied for draft of all plows as confirmation from coefficients of determination $\left(\mathrm{R}^{2}\right)$ which are roughly 0.9 . Hence, it is expected that the developed program package can be used 
to estimate tractor power to match such implements by simple calculations from the predicted draft.

\section{ACKNOWLEDGEMENTS}

The authors express their gratitude to the National Plan for Science, Technology and Innovation Program, King Saud University, Saudi Arabia for financially supporting this research effort as a part of the project entitled "Modeling of energy consumption during seed bed preparation operation based on soil mechanical properties", No. 09-SPA876-02.

\section{REFERENCES}

Aboukarima, A. M. (2007). Draft models of chisel plow based on simulation using artificial neural networks. Misr J. Ag. Eng., 24(1): 42-61.

Aboukarima, A. M. (2013). Evaluation of using a combination of simulated and experimental data to predict draft force of a moldboard plow. Misr J. Ag. Eng., 30 (1): 1 - 28

Aboukarima, A.M. (2004). Artificial neural networks configuration for predicting performance of tillage implements under Egyptian conditions. PhD Thesis, Agric. Eng. Dept., Faculty of Agric., Ain Shams University, Egypt.

Aboukarima, A.M. and A.F. Saad (2006). Assessment of different indices depicting soil texture for predicting chisel plow draft using neural networks. Alexandria Science Exchange J., 27(2): 170-180.

Aboukarima, A.M., M.N. El Awady, A.G. El Kabany and M.H.A. Kabeel (2003). Plows performance under Egyptian conditions depicted by artificial neural networks. Misr J. Agric. Eng., 20 (4): 919-936.

Adamchuk , V. I., A. V. Skotnikov, J. D. Speichinger and M. F. Kocher (2003). Instrumentation system for variable depth tillage. ASAE Paper number 031078, ASAE Annual International Meeting July 27-30, 2003.

Alam, M. M. (1989). Soil reaction forces on agricultural disk implements. PhD Thesis, University of Newcastle, UK. 
Alam, M., M.M. Hossain, M.A. Awal (2001). Selection of farm power by using a computer system. AMA, 32(1):65-68.

Al-Hamed, S.A. and M. F. Wahby (2013). Unpublished final report for the project entitled "Modeling of energy consumption during seed bed preparation operation based on soil mechanical properties", No. 09-SPA876-02. National Plan for Science, Technology and Innovation Program, King Saud University, Saudi Arabia.

Al-Hamed, S.A. and A.A. Al-Janobi (2001). A program for predicting tractor performance in Visual C++. Comput. Electron. Agric. 3 (2001), 137-149.

Al-Hamed, S.-A., R.D. Grisso, F.M. Zoz and K.Von Bargen (1994). Tractor performance spreadsheet for radial tires. Comput. Electron. Agric. 10 (1994), 45-62.

Alhassan, J. K. and S. Misra (2011).Using a weightless neural network to forecast stock prices: A case study of Nigerian stock exchange. Scientific Research and Essays, 6 (14):2934-2940.

Alimardani, R., Y. Abbaspour-Gilandeh, A. Khalilian, A. Keyhani and S. H. Sadati (2009). Prediction of draft force and energy of subsoiling operation using ANN model. Journal of Food, Agriculture \& Environment Vol.7 (3\&4) : 537 - 542.

Al-Jalil, H. F, A. Khdair and W Mukahal (2001). Design and performance of an adjustable three-point hitch dynamometer. Soil \& Tillage Research , 62(3):153-156.

Al-Janobi, A. (2000). A Data-acquisition System to Monitor Performance of Fully Mounted Implements. Journal of Agricultural Engineering Research - J AGR ENG RES. 01/2000; 75(2):167-175.

Al-Janobi, A. A., M. F. Wahby and M. A. Al-Belakhy (1998). A laptop computer based data acquisition system to monitor tractor performance. ASAE, paper No: 98-3108.

Al-Janobi, A., S. Al-Hamed and A.M. Aboukarima (2010). An excel spreadsheet to estimate performance parameters for chisel plow- 
tractor combination based on trained an artificial neural network. Bulletin USAMV Agriculture, 67(2):1-9.

Al-Janobi, A., S. Al-Hamed S. and A. M. Aboukarima (2010). Educational visual $\mathrm{C}++$ program aid to estimate fuel consumption for tillage equipment based on trained artificial neural network. Bulletin of University of Agricultural Sciences and Veterinary Medicine Cluj-Napoca. Agriculture 2010 Vol. 67 No. 1 pp. 309.

Al-Janobi, A.A. and S.A. Al-Suhaibani (1995). Setup of a calibration rig in a mobile instrumentation package. Alexand. J. Agric. Res., 40: 115.

Al-Janobi, A.A. and S.A. Al-Suhaibani (1996). Performance of a three point linkage-implement depth transducer. Misr J. Agric. Eng., 13: 545-557.

Al-Janobi, A.A. and S.A. Al-Suhaibani (1998). Draft of primary tillage implements in sandy loam soil. Applied Engineering in Agriculture, 14(4):343- 348 .

Al-Janobi, A.A., A.M. Aboukarima and K.A. Ahmed (2001). Prediction of specific draft of different tillage implements using neural networks. Misr J. Agric. Eng., 18 (3): 669-714.

Al-Janobi, A.A., S.A. Al-Suhaibani, A.A. Bedri and A.S. Babeir (1997). A precision wheel torque and weight transducer for most common agricultural tractors. Agric. Mech. Asia Afr. Latin Am., 28: 13-17.

Al-Suhaibani, S.A. and A.A. Al-Janobi (1996). An instrumentation system for measuring field performance of agricultural tractors. Misr J. Agric. Eng., 13: 516-528.

Al-Suhaibani, S.A., A.A. Al-Janobi and Y.N. Al-Majhadi (2010). Development and Evaluation of Tractors and Tillage Implements Instrumentation System. American J. of Engineering and Applied Sciences 3 (2): 363-371, 2010.

Al-Suhaibani, S.A., A.A. Bedri, A.S. Babeir and J. Kilgour (1994). Mobile instrumentation package for monitoring tractor 
performance. Agricultural Engineering Research Bulletin No. 40, King Saud University, Riyadh, pp: 26.

Altinisik, A., H. Terzioglu, H. Saglam and K. Altinisik (2012). Analysis of tractor traction force with artificial neural networks in cultivation. 16th International Research/Expert Conference "Trends in the Development of Machinery and Associated Technology" TMT 2012, Dubai, UAE, 10-12 September 2012:567-570.

Aluko, O.B. and D.A. Seig (2000). An experimental investigation of the characteristics of and conditions for brittle fracture in twodimensional soil cutting. Soil \& Tillage Research, 57:143-157.

Amara, M., I. Guedioura and M. A. Feddal (2013). Experimental model to estimate draft force for mouldboard ploughs; incorporating effects of plough geometric . Int. J. Adv. Agric. Res.,1:27-36.

Askari, M. and S. Khalifahamzehghasem (2013). Draft Force Inputs for Primary and Secondary Tillage Implements in a Clay Loam Soil. World Applied Sciences Journal 21 (12): 1789-1794.

Bentaher, H., E. Hamza, G. Kantchev, A. Maalej and W. Arnold (2008). Three-point hitch-mechanism instrumentation for tillage power optimization. Biosystems Engineering, 100 (1):24-30.

Brown, D. P. (2005). Artificial Intelligence for Creation of Rapid, LowCost Models and Simulations. Defense Acquisition University, Technology and Engineering. Department, Fort Belvoir,VA,22060 http://www.dtic.mil/dtic/tr/fulltext/u2/a484107.pdf.

Carman, K. and A. Taner (2012). PREDICTION OF TIRE TRACTIVE PERFORMANCE BY USING ARTIFICIAL NEURAL NETWORKS. Mathematical and Computational Applications, Vol. 17, No. 3, pp. 182-192.

Catalan, H., P. Linares and V. Mendez (2008). Tractor PT: A traction prediction software for agricultural tractors. computers and electronics in agriculture $6: 289-295$. 
Choi, Y. S. ; L.Kyu Seung and W. P. Yeop (2000). Application of a neural network to dynamic draft model. Agricultural and Biosystems Engineering,1(2):67-72.

Dahab, M.H., O.E. Mohamed (2006). A computer model for selection of farm machinery. U. K. J. Agric. Sci. 14(2):167-181.

El Awady, M.N., A.G. El Kabany, M.H.A. Kabeel and A.M. Aboukarima (2004). Predicting unit draft of tillage implements using statistical models and neural networks. The $12^{\text {th }}$ Conf. of Misr Society Agric. Eng., 15-16 October, Alexandria Univ.: 139-249.

El Awady, M.N., A.G. El Kabany, M.H.A. Kabeel, and A.M. Aboukarima (2003). Relative importance of variables affecting chisel-plow performance using neural networks. The $11^{\text {th }}$ Conf. of Misr Society Agric. Eng., 15-16 October, Rice Mech. Centre, Meet El Deeba, Kafer El Sheikh Governorate: 395-407.

El Awady, M.N.; A.G. El-Kabany; M.H. Kabeel and A.M. Aboukarima (2002). Using neural networks and linear regression for predicting energy requirements in plowing. The 10th Conf. of Misr Soc. of Ag. Eng.: 115126 (In Arabic).

El Khadrawy, A.A. (1990). Estimating of used energy in the production of some Egyptian crops. MSc. Theses, Agric. Mech. Dept., Fac. of Agric., Mansoura Univ.: 71-140.

Elashry, E. R., A.M. Bassuni, A. A. Sayed Ahmed and K.A.Ahmed (1994). An instrumentation system for measuring the tractor performance. Misr J. Agric.Eng.11 (4):968-987.

Elbanna, E.B. (1989). Prediction of specific moldboard plow draft. J. Agric. Sci. , Mansoura Univ., 15 (2):253-265.

Elbanna, E.B. (1992). Tillage tools draft: chisel and moldboard plows. Misr J. Ag. Eng., 9 (4): 491-510.

Fishman, G.S. (1973). Concepts and methods in discrete event digital simulation. John Wiley and Sons, New York, pp150. 
Formato, A., S. Faugno and G. Paolillo (2005). Numerical simulation of soil-plow moldboard interaction. Biosystems Engineering, 92 (3):309-316.

Gee-Clough, D., M. McAllister, G. Pearson and D.W. Evernden (1978). The empirical prediction of tractor - implement field performance. J. of Terramechanics, 15(2):81-94.

Godwin, J. and M.J. O'Dogherty (2007). Integrated soil tillage force prediction models. J. of Terramechanics, 44 (1):3-14.

Godwin, R.J., M.J. O’Dogherty, C.Saunders and A.T. Balafoutis (2007). A force prediction model for moldboard plows incorporating the effects of soil characteristic properties, plow geometric factors and plowing speed. Biosystems Engineering, 97:117-129.

Graham, W. D., L. D. Gaultney and R. F. Cullum (1990). Tractor Instrumentation for Tillage Research . Applied Engineering in Agriculture. 6(1): 24-28.

Graves, A. R., T. Hess, R. B. Matthews, W. Stephens, and T. Middleton (2002). Crop simulation models as tools in computer laboratory and classroom-based education. J. Nat. Resour. Life Sci. Educ., 31:4854.

Hassan I. M.,S. I. M. N. Gabir,M. A. A. Omer ,O. M. Abbas ( 2011). A program for predicting performance of agricultural machinery in Visual Basic. Research Journal of Agriculture and Biological Sciences, 7(1): 32-41.

Hassan, A.E. and A.S.Tohmaz (1995). Performance of skidder tires in swamps-comparison between statistical and neural network models. Transaction ASAE, 38 (5): 1545-1551.

Hesse, H. and Keuper, G. (2001). Mass flow-control on hydraulically driven disc spreaders. In: Duhovnik, et al., (2004). Analysis and design parameters for inclined rotors used for manure disposal and broadcast spreaders for solid manure. Transactions of the ASAE, 47(5): $1389-1404$. 
Huijsmans, J. F. M., J. G. L. Hendriks and G. D. Vermeulen (1998). Draft requirement of trailing-foot and shallow injection equipment for applying slurry to grassland. J. agric. Engng Res., 71:347-356.

Hwang HB (2001). Insights into neural network forecasting of time series corresponding to ARIMA (p,q) structures. Omeg,. 29: 273- 289.

In Kawuyo, U. A. (2011). Mathematical modelling of draft characteristics of selected animal-drawn implements on the upland soils of Samaru, Nigeria. PhD Thesis, Department of Agricultural Engineering, Faculty of engineering, Ahmadu Bello University, Zaria:194p.

In Kawuyo, U. A. (2011). Mathematical modelling of draft characteristics of selected animal-drawn implements on the upland soils of Samaru, Nigeria. $\mathrm{PhD}$ Thesis, Department of Agricultural Engineering, Faculty of engineering, Ahmadu Bello University, Zaria:194p.

KarimiInchebron, A., S. R. M. Seyedi and R. T. Koloor (2012). Investigating the effect of soil moisture content and depth on the draft, specific draft and drawbar power of a light tractor. International Research Journal of Applied and Basic Sciences, 3 (11): 2289-2293.

Kawuyo, U. A. (2011). Mathematical modelling of draft characteristics of selected animal-drawn implements on the upland soils of Samaru, Nigeria. PhD Thesis, Department of Agricultural Engineering, Faculty of engineering, Ahmadu Bello University, Zaria:194p.

Kawuyo, U. A. (2011). Mathematical modelling of draft characteristics of selected animal-drawn implements on the upland soils of Samaru, Nigeria. PhD Thesis, Department of Agricultural Engineering, Faculty of engineering, Ahmadu Bello University, Zaria:194p.

Kheiralla, A.F., A. Yahya, M. Zohadie and W. Ishak (2004). Modelling of power and energy requirements for tillage implements operating in Serdang sandy clay loam, Malaysia. Soil \& Tillage Research, 78:21-34. 
Kushwaha, R.L. and Z. X. Zhang (1997). Artificial neural networks modeling of soil-tool interaction.ASAE Paper No. 97-3067, ASAE, St. Joseph, Michigan, USA: 1-11.

Lai, Q., H. Yu,H. Chen and Y. Sun (2010).Prediction of total power of agricultural machinery using artificial neural networks. Proceeding CCIE '10 Proceedings of the 2010 International Conference on Computing, Control and Industrial Engineering - Volume 02:394396.

Lar, M.B., Z. K. Pour, and G. R. Bamimohammadi (2011). Field efficiency and its use for energy coefficient determination. J. of American Science, 7(8):599-603.

Lendaris, G. (2004). Supervised learning in ANN from introduction to artificial intelligence, New York, April 7.

Leonard, J., and M.A. Kramer (1990). Improvement of the backpropagation algorithm for training neural networks. Comp. Chem. Eng, 14, 337-341.

Lippmann, R.P. (1987). An introduction to computing with neural nets. IEEE Magazine, April:4-22.

Mahfoud, A. and G. Ilham (2013). A force prediction model for the plough introducing its geometrical characteristics and its comparison with Gorjachkin and Gee Clough models. Erudite Journal of Engineering sciences and Technology (EJEST), 1(1):1-7.

Manuwa, S.I. and M.O. Ogunlami (2010). Soil-tool interaction modeling of parameters of soil profile produced by tillage tools. J. Eng. and Applied Sci. , 5:91-95.

Medeiros, M.C. and C.E. Pedreira (2001). What are the effects of forecasting linear time series with neural networks. Eng. Intell. Syst., 4: 237- 424.

Moeenifar, A. , S.R M. Seyedi and D. Kalantari (2013b). Determination of traction force acting on a wide blade using dimensional analysis Method. Intl J Agri Crop Sci., 5 (13):1403-1409. 
Moeenifar, A. M., D. Kalantari and S. R. M. Seyedi (2013a). Application of dimensional analysis in determination of traction force acting on a narrow blade. Intl J Agri Crop Sci., 5 (9):1034-1039.

Mohammadi A., R.Alimardani, A. Akbarnia and A.Akram (2012). Modeling of draft force variation in a winged share tillage tool using fuzzy table look-up scheme. December, 2012 Agric Eng Int: CIGR Journal, 14(4):262-268.

Mouazen, A.M and H. Ramon (2002). A numerical-statistical hybrid modeling scheme for evaluation of draft requirements of a subsoiler cutting a sandy loam soil, as affected by moisture content, bulk density and depth. Soil \& Tillage Research, 63 (3-4): 155-165.

Muthuri, C.W. (2004). Models. The Green Book: A guide to effective graduate research in African agriculture, environment and rural development. Edited by Patel, B.K., K. Muir-Lerescher, R. Coe and S.D. Hainswort. African Crop Science Society, Kampala, Uganda.

Nadre, R.G. and R.K. Datta (1991). Investigation on forces in three-point linkage of tractor. Journal of Agricultural Engineering, India Society of Agricultural Engineering, Vol. XXVIII, Nos. 1 To 4:254260 .

Nkakini, S. O. and I.E Douglas (2012). Modeling tractive force requirements of wheel tractors for disc harrowing in loamy sand soil. International Journal of Engineering and Technology, 2 (10):1657-1665.

Olatunji, O.M. and R.M. Davies (2009). Effect of weight and draft on the performance of disk plow on sandy-loam soil. Research Journal of Applied Siences, Engineering and Technology, 1(1):22-26.

Oskoui, K. E. and B. D. Witney (1982). The determination of plow draft, part 1: prediction from soil and meteorological data with cone index as the soil strength parameter. J. of Terramechanics, 19: 97-106.

Oskoui, K. E., D. H. Rackham and B. D. Witney (1982). The determination of plow draft: part 2, the measurement and prediction 
of plow draft for two moldboard shapes in three soil series. J. of Terramechanics, 19: 153-154.

Powell, G. (2000). Selection and matching of tractors and implements. DPI's Agency for Food and Fibre Sciences. File No: FS0305. Date created: $\quad$ September $2000 . \quad$ Revised: N/A. http://www2.dpi.qld.gov.au/fieldcrops/3492.html.

Pranav, P. K., T. Patel, M. Rathore and A. J. Sonowal (2012). Computer Simulation for Haulage Performance of Power Tiller. International Journal of Computer Applications (0975 - 8887) Volume 58- No.5, November 2012:19-25.

Rahman, A., R.L. Kushawaha, S.R. Ashrafizadeh and S. Panigrahi (2011). Prediction of energy requirement of a tillage tool in a soil bin using artificial neural network. ASABE Paper No. 111112. American Society of Agricultural and Biological Engineers, St. Joseph, Michigan, USA.

Rashidi , M., H. F. Lehmali, M. S. Beni, M. Malekshahi and S. T.i Namin (2013). Prediction of disc harrow draft force based on soil moisture content, tillage depth and forward speed. Middle East Journal of Scientific Research, 15(2):260-265.

Rashidi, M., I. Najjarzadeh, B. Jaberinasab, S. M. Emadi and M. Fayyazi (2013). effect of soil moisture content, tillage depth and operation speed on draft force of moldboard plow. Middle-East Journal of Scientific Research, 16 (2): 245-249.

Roul, A.K., H. Raheman, M.S. Pansare and R. Machavaram (2009). Prediction of draft requirement of tillage implements in sandy clay loam soil using an artificial neural network. Biosystems Engineering, 104(4): 476-485.

Sahu, R. K. and H. Raheman (2006). An approach for draft prediction of combination tillage implements in sandy clay loam soil. Soil \& Tillage Research 2006; 90(1):145-155. 
Sahu, R.K. and H. Raheman (2006). Draft prediction of agricultural implements using reference tillage tools in sandy clay loam soil. Biosystems Engineering, 94 (2):275-284.

Saleh, B. and A. A. Aly (2013). Artificial neural network model for evaluation of the ploughing process performance. International Journal of Control, Automation and Systems, 2 (2):1-11.

Shinde, G. U. and S. R. Kajale (2011). Computer aided engineering analysis and design optimization of rotary tillage tool components. Int J Agric \& Biol Eng, Vol. 4 No.3: 1-6.

Shinde, G. U.1, J.M.Potekar, R.V.Shinde and S.R.Kajale (2011). Design analysis of rotary tillage tool components by CAD-tool: rotavator. International Conference on Environmental and Agriculture Engineering IPCBEE vol.15 (2011), IACSIT Press, Singapore:1-6.

Shirgure P. S. and G. S. Rajput (2011). Evaporation modeling with neural networks-A Research review. International Journal of Research and Reviews in Soft and Intelligent Computing (IJRRSIC), 1(2):37-47.

Shrestha, D. S., G. Singh and G. Gebresenbet (2001). Optimizing design parameters of a moldboard plow.J. agric. Engng Res., 78 (4): 377 389.

Smith, L.A. (1993). Energy requirements for selected crop production implements. Soil and Tillage Research, 25:281-299.

Sogaard, H.T. and C.G. Sorensen (1996). A model for optimal selection of machinery sizes within the farm machinery system. Sixth International Conference on Computers in Agriculture, American Society of Agricultural Engineers, St. Joseph, Michigan, USA: 588596.

Taghavifar, H. , A. Mardani and I. Elahi (2013b). Preliminary researches regarding the use of ANN to predict the wheel-soil interaction. Agronomical Research in Molodivia, Vol. XLVI , No. 1 (153):5-13. 
Taghavifar, H. and A. Mardani (2013a). Use of artificial neural networks for estimation of agricultural wheel traction force in soil bin. Neural Computing and Applications, DOI:10.1007/s00521-013-1360-8.

Taghavifar, H. and Mardani (2013b). A. Application of artificial neural networks for the prediction of traction performance parameters. Journal of the Saudi Society of Agricultural Sciences (2013), http://dx.doi.org/10.1016/j.jssas.2013.01.002.

Taghavifar, H., H. Kalbkhani, A. Mardani and H. K. Maslak (2013a)Artificial Neural Network estimation of wheel rolling resistance in clay loam soil. Applied Soft Computing, Volume 13, Issue 8, August 2013, Pages 3544-3551

Tohmaz, A.S. and A. E. Hassan (1995). Application of artificial neural networks to skidder traction performances. J. of Terramechanics, 32 (3): 105-114.

Vesta Services (2000). Vesta Services, Inc. Qnet2000 Shareware, Vesta Services, Inc., 1001 Green Bay Rd, STE 196, Winnetka, IL 60093.

Vishal, B., S. Surendra and P. K. Gupta (2013). Predicting tractor power requirements using decision support system - a tool for farm machinery management. Agricultural Engineering Today, 37(1): 7- 14.

Younis, S. M., E. R. Elashry, A. F. Bahnasy and I. M. Elsybaee (2010). Development a local system for measuring tractors performance. Misr J. Ag. Eng., 27(1): 34 - 53.

Yousif, L. A., M.H. Dahab and H. R. El Ramlawi (2011). Cropmachinery management system for field operations and farm machinery selection. Journal of Agricultural Biotechnology and Sustainable Development, 5(5):84-90.

Zhang GP (2001). An investigation of neural networks for linear time series forecasting. Comput. Operat. Res., 28: 1183-1202.

Zhang, D., Q. Jiang and X. Li (2005). Application of neural networks in financial data mining. International Journal of Computational Intelligence, 1:106-109. 
Zhang, Z.X. and R. L. Kushawaha (1999). Application of neural networks to simulate soil-tool interaction and soil behavior. Canadian Agricultural Engineering, 41(2): 119-125.

\section{الملخص العربي

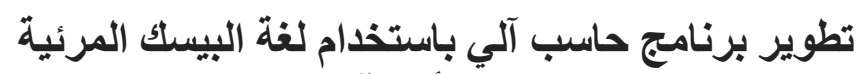

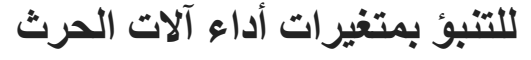

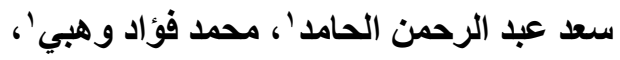

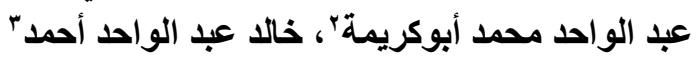

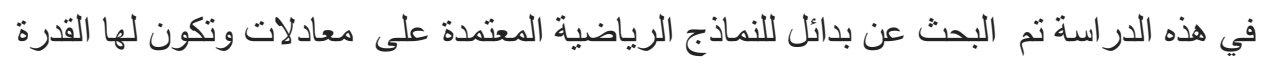

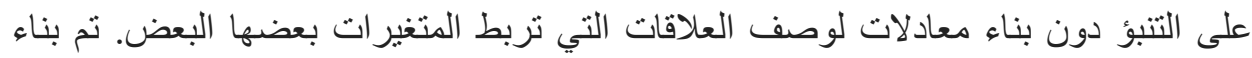

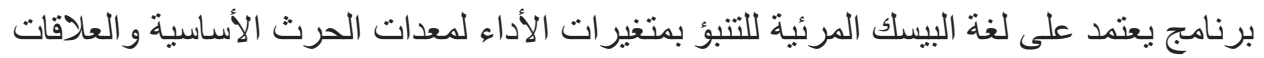

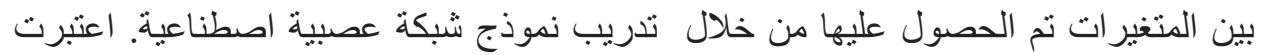

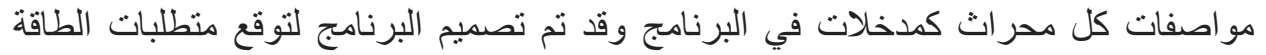

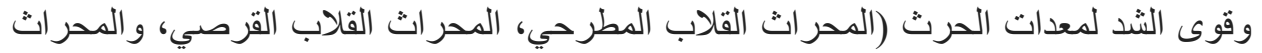

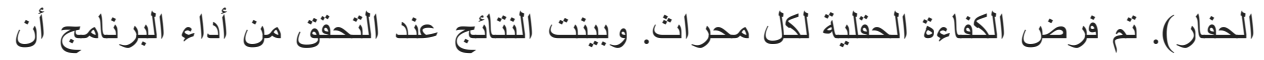

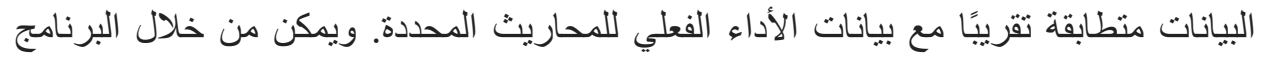

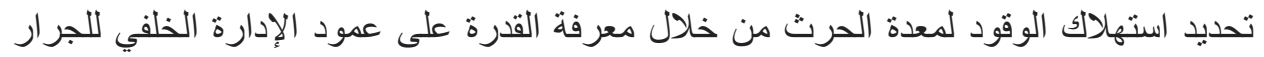

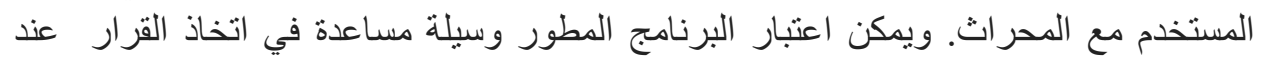

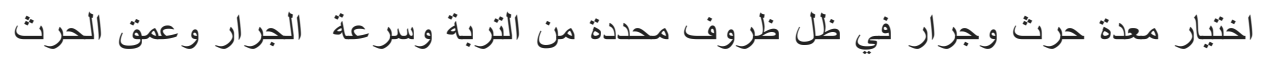

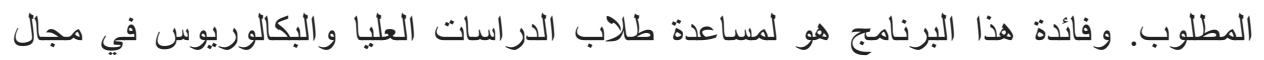

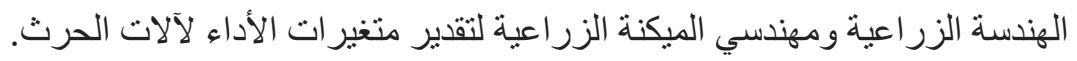

' أستاذ ـ قسم الهندسة الزراعية، كلية علوم الأغذية والزراعة. جامعة الملك سعود، السعودية.

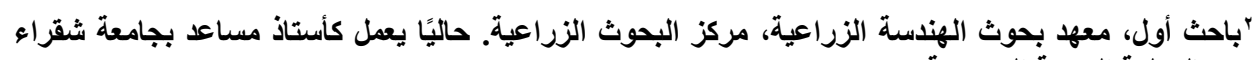

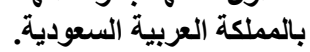
"باحث، معهد بحوث الهندسة الزراعية، مركز البحوث الزراعية. حائيًا يعمل كأستاذ مساعد بجامعة الملك سعود

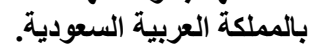

